\title{
ADDIE MODEL FOR DEVELOPMENT OF E-COURSES
}

\section{Dalibor Drljača', Branko Latinović2, Željko Stanković2, Dragan Cvetković}

\author{
${ }^{1}$ Europrojekt centar, \\ Banja Luka \\ ${ }^{2}$ Apeiron University, \\ Banja Luka \\ ${ }^{3}$ Singidunum University, \\ Belgrade
}

\begin{abstract}
:
This paper gives a review of ADDIE model used in the preparation of teaching materials for use in electronically supported teaching process generally, and especially for electronic learning. ADDIE model proved itself as the very useful instructional model in preparation of materials for traditional teaching and there is a strong intention to use this model for electronic and on-line teaching materials.
\end{abstract}

Keywords:

ADDIE model, instructional model, e-Learning, materials.

\section{INTRODUCTION}

Nowadays, e-learning requires significant financial support, in particular, initial investments, such as the establishment of e-learning infrastructure. This refers both to hardware as well as software, although there are many open solutions that might meet your demands. Second most important costs are the cost for preparation of quality education content and teaching materials. To that end, one has to add spent time and eventual costs of training educational system users. The mentioned resources will be better used if adequate pedagogic and methodical principles were applied in the process of selection and creation of teaching content and e-learning system in general.

At the very beginning of the implementation of the Internet and Web in e-learning, the first step in the delivery of teaching materials was the simple provision of teaching materials in the on-line form. This was a limiting factor that contributed to the low quality of teaching materials due to the lack of adequate supportive technologies we have today. This

Correspondence:

Dalibor Drljača

e-mail:

drljacad@gmail.com limitation prevents implementation of any proper pedagogic method. Nevertheless, these were the initial pioneering steps in e-learning. However, today it is very important to foresee and to precisely define, for any course or materials, firstly the teaching conditions, learning objectives and target group of students in order to maximise the effects of learning outcomes. 


\section{INSTRUCTIONAL DESIGN}

The instructional design presents the practice of creating "instructional experiences which make the acquisition of knowledge and skills more efficient, effective, and appealing." [1] In modern e-learning systems, instructional design is based on a combination of behavioural, cognitive and constructivist theories of learning due to the nature of virtual learning environment. These theories provide an insight in learning process and achievement of learning outcomes making modern e-learning successful.

For example, constructivism suggests that student should bear responsibility for their own learning. This is due to the fact that transfer of knowledge is far from simple, and being proactive student contributes to the better construction of knowledge in students' conscience. Therefore, the student is motivated to create new idea only if actively involved in the learning process. Group work can also contribute to exchange of experiences with other students, while at the same time enables a deeper understanding of learning material. It is clear that constructivist learning model includes investigative activities of students and development of social and educational communication channels. Investigative approach by student involves making mistakes as important part of learning process. While learning, the student develops his/her own education culture that results with growth in the student learning autonomy [2].

According to Ertmer and Newby, behavioural strategies and recommendations for instructional design are primarily used in the studying of facts, cognitive strategies in the study of processes and principles, while constructivist strategies are used for support of advanced thinking that promotes personal knowledge, situated and contextualised learning [3].

Therefore, the instructional design provides recommendations for the planning of the learning process in e-learning systems, as well as precise steps that should be followed during the process of creation of an electronic course. It is possible to distinguish three general phases in the process of preparation of an e-course: the creation of e-course, implementation and evaluation of created e-course [4].

Creation of e-course is based on the activities related to the planning of teaching process, and for this is necessary to define:

- General learning objectives (content, of course, essence of content, wishes of students, students' motivation and expectations)
- Target groups (identification of individual student characteristics and previously acquired skills and knowledge and defining of general characteristics of the group)

- Teaching methods (how to use modern information and communication technologies (ICT) in learning process)

- Resources (review of technical and pedagogic aspects of resources available for implementation of e-course and training of teachers to use these ICTs in learning process in the more effective manner)

- Learning environment (to define how it is going to be used - as place for simple distribution of information, as data storage, or as interactive environment and environment for sharing knowledge between significant number of students)

- Learning material (creation of multimedia material or materials in electronic form)

The implementation phase means monitoring of learning process and review of aspects that teachers should take into account for the implementation of e-learning. At this stage individual characteristics of students are studied, the means of interaction and the general rules of work in the "on-line" environment.

The evaluation process of learning and student assessment must be consistent with the goals of learning so that the evaluation is carried out through all the activities that help achieve these goals. Based on the feedback, the teacher continues to guide students in the process of acquiring knowledge. The assessment of students is one of many forms of evaluation.

\section{ADDIE MODEL}

The ADDIE model was initially developed by Florida State University in order to explain "the processes involved in the formulation of an instructional systems development (ISD) program for military inter-service training that will adequately train individuals to do a particular job and which can also be applied to any interservice curriculum development activity." [5] The steps were revised over the years and eventually the model itself became more dynamic and interactive than its original. Its most popular version appeared in the mid-80s, as we understand it today.

Considering previously mentioned pedagogic aspects of learning and their effect on the creation of e-course, ADDIE model is perhaps the most popular model used 
for the creation of learning materials. The name is an acronym of the phrase - Analyse, Design, Develop, Implement, Evaluate [6]

It is important to emphasize that the creation of a course in this model is an iterative process (repetitive) during which the creator of the course can return to any previous stage of course development, depending on the results of the evaluation carried out in all stages of development, but also at the end of the course.

ADDIE model does not suggest follow-up of any of the three theories of learning but represents a project management tool that helps in the preparation of the ecourse and instructional design taking into account all the factors that may affect the quality of course.

\section{Analysis}

The analysis is the first step of ADDIE model in the design of courses and teaching materials for on-line teaching and learning. At this stage, it is necessary to create the "overall picture" of the instructional design integrity. This is a "contemplative" stage where it is necessary to think about the student-centered approach for the design of course or of materials. The analysis, in fact, presents a "planning phase" in which it is necessary to identify the basic parameters that will be traceable in other phases of the ADDIE model. The adopted parameters must be quantitatively and qualitatively defined as much as possible for the purpose of evaluation in all other phases of the model and after implementation based on the feedback from students and the thinking of teachers who realise the educational process.

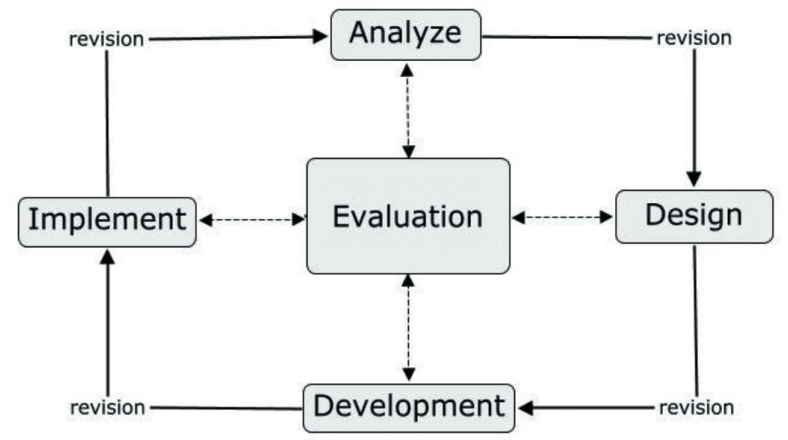

Fig. 1. ADDIE model iterative process (from Educational Technology [7])

In order to ensure successful results from the overall process, at this stage it is necessary to set up a series questions dealing with: course design, target groups, learning objectives, content identification, presentation environment for content (on-line, on-demand, vis-à-vis, printed, CD...), teaching and learning strategies, other possible limitations. Very important question is also - how to ensure the quality of the whole process?

The analysis refers to the gathering of information about one's audience, the tasks to be completed, how the learners will view the content, and the project's overall goals. Upon collection, instructional designer can classify the information to make more effective and applicable content.

Some common tasks and questions related to this stage are:

- To define the overall background of students (personal and educational information, age, nationality, previous experience and interests).

- To define learning outcomes and learning needs (what results should be achieved, what knowledge should be adopted...)

- To define adequate learning environment and delivery options (virtual, live, on-line discussions, face-to-face, blend)

- To define learners' knowledge and skills required (specific skills required or not, skills in case of disabled persons participating...)

- To define all pedagogical considerations, especially in the case of on-line course (adequacy of selected approach, adequacy of selected methodology, constraints...)

- To define overall project objectives (instructional goals, learning goals, teaching goals...)

- To define necessary resources for the project (technical, human, time, skills...) as well as their influence on effectiveness and achievement of project objectives.

\section{Design}

In this phase, instructional designers begin to create their project. The information gathered from the analysis phase, in conjunction with the theories and models of instructional design, is meant to explain how the learning will be acquired. For example, the design phase begins with writing a learning objective. Tasks are then identified and broken down to be more manageable for the designer. The final step determines the kind of activities required for the audience in order to meet the goals identified in the analysis phase. 
In the design stage, it is necessary to create a draft or framework of the course and to start with the construction of course structure. This means that it is necessary to have all and accurate guidelines for the creation of course structure as defined during analysis phase including the schedule on the unfolding of the course, the arrangement of individual lessons during the course, the shape of the teaching strategy and all necessary resources to in accordance with the given schedule.

Design phase includes additional detailed planning of the following:

- Educational goals, or learning objectives,

- Educational content (lessons),

- Methods,

- Selected method and frequency of assessment,

- Use of on-line technologies for knowledge presentation,

- Methods and frequency of communication with participants (target group).

Some common tasks and questions related to this stage are:

- To define the type of media used (audio/video/ graphics, own or third party...)

- To define teacher's style approach (behaviourist, constructivist etc.)

- To define the level and types of activities generated by the study (collaborative, interactive, individual...)

- To define a timeframe for each activity (hours, lessons, modules, scalability, and dependencies in workflow...)

- To define precisely skills and knowledge developed (mental skills, cognitive skills...)

- In the case of web-based e-learning, complete definition of user interface (look of the site, functionalities...)

- To define feedback mechanisms on digestion of the lessons (technical solutions, questionnaires, brief exams...)

\section{DEVELOPMENT}

The development phase involves the transition from the "contemplative" to "physical" implementation. At this stage, the final structure and content of the course are created in accordance with all the elements and parameters defined in the previous two phases.
Development implies close cooperation between the author of the course and the person in charge of the technical performance of the material for the course will be set to "on-line" mode. This involves teamwork, except in the case where the teacher is also the supplier of multimedia content prepared for a specific platform, for example, LCMS (Learning Content Management System). This phase this is very important synergy between teacher and content producer, in cases where teachers are not managing creation and maintenance of course materials. The teacher must be able to transform a vision of a class in order to set up such virtual classroom with all required functionalities.

Given the technical possibilities of LCMS, it is necessary to obtain and prepare the technology for presenting the content, interactions with students, as well as to plan activities for students' teamwork and work at home, or "off-line".

The Development phase is all about putting it into action. This phase includes three main tasks: drafting, production and evaluation. Development thus involves creating and testing of learning outcomes.

Some common tasks and questions related to this stage are:

- Ensure teamwork of all (optimal capacity performance by all involved, effective work of all members...)

- Ensure timely submission and preparation of learning materials (creation of materials per defined schedule, in time preparations...)

- Ensure production of materials per task intended for (no extra work or sufficient materials should appear).

- Ensure prototyping for evaluation purposes (testing, checking, and making possible corrections)

\section{IMPLEMENTATION}

The implementation phase represents the first test of making the entire course and is therefore recommended to divide this phase conditionally into two parts: a test implementation phase and final implementation phase. Test implementation should confirm the integrity and functionality of the created course and the accompanying materials and access to the exchange rate at the moment are limited to the teachers and administrators of the system, possibly to test-users. If the integrity and functionality of the course are confirmed, then the course can be officially in "on-line" mode and available to all students accredited 
for access. The final means of implementation in addition to setting "on-line" mode, and preparing students for the use of educational materials and technology, but also for information on all the details of implementation of the course, especially about its structure and dynamics tests.

During the implementation phase, a procedure for training the facilitators and the learners is developed. The facilitators' training should cover the course curriculum, learning outcomes, a method of delivery, and testing procedures. Preparation of the learners includes training them on new tools (software or hardware), student registration.

This is also the phase where the project manager ensures that the books, hands on equipment, tools, CDROMs and software are in place and that the learning application or Web site is functional.

Some common tasks and questions related to this stage are:

- To evaluate the emotional feedback from teachers and students during initial demonstration of the project (genuinely interested, eager, critical or resistant)

- To prepare backup plans for any possible error during testing (format of media, convertors, ...)

\section{EVALUATION}

ADDIE model makes it possible to define two types of evaluation: intermediate (formative) and summative (see Figure 2).

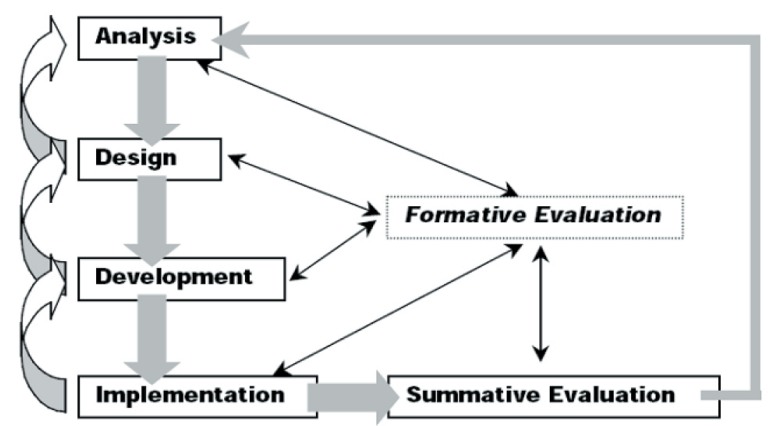

Fig. 2. Advanced (improved) ADDIE model [8].

Some common tasks and questions related to this stage are:

- To define the categories within which the project effectiveness can be achieved (improved learning, better motivation etc.,)
- To define data collection policy (including strategy, timing, frequency, tools...)

- To ensure analysis of feedback from all participants in the system (instructors, students, ...)

- To set-up quality assurance tools for clarity of instructions, reliability and content validity (different tools or the same)

- To define final output and holder of report preparation (will it be an instructor, manager, ...)

\section{WEAKNESS OF ADDIE MODEL}

This model has been primarily used for years to develop multimedia learning content, as other models also revealed some weaknesses in realisation. Probably the biggest problem with this model is the assumption that the author knows in advance all the requirements, or even before the development of the content, but these deficiencies are as follows [9]:

1. typical processes require an unrealistic and comprehensive analysis in advance,

2. Ignoring the policy of reality causes strong likelihood that vital resource will be missing and will use a high degree of improvisation in implementation,

3. The details of the process are set so that creativity presents an obstacle,

4. The inconvenience of dealing with errors or good ideas in the process,

5. The learning program is designed to meet the measured criteria (schedule, costs, pass), but it is not able to track behavioural change,

6. Post-tests provide little useful information that would help improve the teaching and learning process.

\section{CONCLUSION}

Even though it is widely represented in current teaching practice, both traditional and electronic teaching, ADDIE model is slowly losing the race against time. This acronym stands for the 5 phases contained in the model (Analyse, Design, Develop, Implement, and Evaluate). Over the years this model was primarily used for the development of multimedia content for learning, but also pointed to some weaknesses. Most of the current instructional design models are variations of the ADDIE process. 
Contemporary requirements for the course in electronic form require great flexibility and adaptability to the needs of the target group of students. It is necessary to properly design/construct the course and accompanying educational materials in order to meet these requirements. One of the solutions that compete to succeed ADDIE model, especially in the field of e-learning and teaching is the SAM (Successive Approximation Model, formerly called SAVVY process) that includes prototyping. The success of SAM lies in the fact that it follows modern agile development principles. The most important difference is that SAM looks for iteration in development with repeated small steps and prototyping, instead perfectly executed big steps. Small, purposeful and iterative steps are facilitating analysis and evaluation processes that clarify pathways to successful design. This gives SAM advantage in respect of creation of performance-driven learning.

\section{REFERENCES}

[1] M. D. Merrill, L. Drake, M. J. Lacy and J. Pratt , "Reclaiming instructional design", Educational Technology 36 (5): 5-7, 1996

[2] M. Mušanović, "Konstruktivistička teorija i obrazovni process", Zbornik skupa: Didaktični in metodični vidiki nadaljnega razvoja izobraževanja, Maribor, Univerza v Mariboru, Pedagoška fakulteta Mariboru, pp.28-35, 2000
[3] Katarina Milosavljević „Učenje na daljinu i e-učenje“, časopis „Partner u učenju elektronski časopis za nastavnike“, Microsoft Srbija Beograd, pp.1-4, 2007

[4] Nataša Popović, Elektrotehnički fakultet, Istočno Sarajevo, Milica Naumović, Elektronski fakultet, Niš „Realizacija elektronskog kursa iz upravljačkih sistema u MOODLE okruženju“, INFOTEHJAHORINA Vol. 8, Ref. E-II-11, pp. 511-515, 2009

[5] R. K. Branson, G. T. Rayner, J. L. Cox, J. P. Furman, F. J. King, W. H. Hannum, "Interservice procedures for instructional systems development" (5 vols.) (TRADOC Pam 350-30 NAVEDTRA 106A). Ft. Monroe, VA: U.S. Army Training and Doctrine Command, August 1975. (NTIS No. ADA 019486 through ADA 019 490)

[6] R. A. Reiser and J. V. Dempsey, "Trends and issues in instructional design and technology", Boston: Pearson, 2012

[7] Website, Educational Technology, http://educationaltechnology.net/the-addie-model-instructionaldesign (accessed on 1.3.2106.)

[8] Steven J. McGriff „Instructional System Design (ISD): Using the ADDIE Model" Instructional Systems, College of Education, Penn State University, 2000

[9] Michael W. Allen, "Leaving the ADDIE Model Behind”, Allen Interactions, 2009 